\title{
AR GALIMA PRADÉTI APKALTĄ SEIMO NARIUI UŽ NUSIKALTIMĄ, PADARYTA IKI TAMPANT SEIMO NARIU
}

Prof. DR. Vytautas Sinkevičius

Mykolo Romerio universiteto Teisés fakulteto

Viešosios teisès institutas

Ateities g. 20, LT-08303 Vilnius

El.paštasv.sinkevicius@mruni.eu

\section{Santrauka}

Straipsnyje nagrinejjama apkaltos samprata, atskleidžiamas apkaltos pagrindu turinys, tyrinejama, kokie asmenys apkaltos proceso tvarka gali būti pašalinti iš pareigų. Nagrinèjama, ar pagal Lietuvos Respublikos Konstitucija apkalta galima tik už veiksmus, kuriuos Konstitucijos 74 straipsnyje nurodyti asmenys padare eidami šiame straipsnyje ịvardytas pareigas, ar apkalta galima ir už veiksmus, padarytus iki užimant nurodytas pareigas. Teigiama, kad apkaltos proceso tvarka Seimo nario mandata galima panaikinti už nusikaltima, kurị asmuo padare iki tapdamas Seimo nariu.

Reikšminiai žodžiai: apkaltos samprata; apkaltos pagrindai; apkaltos teisinès pasekmès.

\section{Ivadas}

Lietuvos apeliacinis teismas $2016 \mathrm{~m}$. vasario $1 \mathrm{~d}$. nuosprendžiu Seimo narị Vytautą Gapši pripažino kaltu padarius nusikaltimą ir skyrẻ 
jam 3,6 tūkst. eurų baudą. Teismo apkaltinamasis nuosprendis įsiteisejjo. Seime kilo iniciatyva Seimo nariui V. Gapšiui pradèti apkaltos procesą, nes jis padarè nusikaltimą. Nepritariantys tokiai iniciatyvai remiasi Seimo statuto 227 straipsniu, pagal kurị Seimo nariui ir kitiems Konstitucijos 74 straipsnyje nurodytiems asmenims apkalta galima tik už veiksmus, padarytus jiems einant Konstitucijos 74 straipsnyje numatytas pareigas, - kadangi V. Gapšys nusikaltimą padarè iki tapdamas Seimo nariu, vadinasi, jam apkalta esą negalima. Tačiau apkaltos iniciatorių tokie argumentai neįtikino, jie reikalavo pradèti apkaltą. Seimas $2016 \mathrm{~m}$. balandžio $7 \mathrm{~d}$. prièmé nutarimą ${ }^{1}$ pradèti apkaltos procesą Seimo nariui V. Gapšiui ir „kreiptis ị Lietuvos Respublikos Konstitucinị Teismą išvados, ar Lietuvos Respublikos Seimo nario Vytauto Gapšio veiksmai prieštarauja Lietuvos Respublikos Konstitucijai ir ar jis gali eiti Lietuvos Respublikos Seimo nario pareigas po to, kai jam isiteisèjo teismo apkaltinamasis nuosprendis“.

Straipsnyje nagrinejjama, ar pagal Konstituciją apkalta galima tik už veiksmus, kuriuos Konstitucijos 74 straipsnyje nurodyti asmenys padaré eidami minètame straipsnyje išvardytas pareigas, ar ir už veiksmus, padarytus iki jas užimant. Daugiausia dèmesio skiriama klausimui, ar apkaltos proceso tvarka Seimo nario mandatą galima panaikinti už nusikaltimą, kuri asmuo padarė iki tapdamas Seimo nariu. Ši problema teisès mokslinèje literatūroje nèra nagrinèta.

Atliekant tyrimą taikomi teisès norminių aktų sisteminès analizès ir apibendrinamasis metodai.

Lietuvos Respublikos Seimo 2016 m. balandžio 7 d. nutarimas Nr. XII-2289 „Dèl apkaltos Lietuvos Respublikos Seimo nariui Vytautui Gapšiui pradžios ir kreipimosi i Lietuvos Respublikos Konstitucinị Teismą“. Teisès aktu registras (TAR), identifikavimo kodas 2016-08285. Prieiga per internetą: https://www.e-tar. lt/portal/index.html. 


\section{Apkaltos samprata}

Konstitucijos 74 straipsnyje nustatyta, kad „Respublikos Prezidentą, Konstitucinio Teismo pirmininką ir teisèjus, Aukščiausiojo Teismo pirmininką ir teisejjus, Apeliacinio teismo pirmininką ir teisèjus, Seimo narius, šiurkščiai pažeidusius Konstituciją arba sulaužiusius priesaiką, taip pat paaiškejjus, jog padarytas nusikaltimas, Seimas 3/5 visų narių balsų dauguma gali pašalinti iš užimamų pareigų ar panaikinti Seimo nario mandatą. Tai atliekama apkaltos proceso tvarka, kurią nustato Seimo statutas“. Galimybė pašalinti asmenị iš pareigų, panaikinti Seimo nario mandatą apkaltos proceso tvarka Lietuvos konstitucinejje sistemoje itvirtinta pirmą kartą ${ }^{2}$. Nė vienoje anksčiau galiojusioje Lietuvos konstitucijoje toks aukščiausių valstybės pareigūnų konstitucinės atsakomybès būdas nebuvo numatytas. Tauta, Konstitucijoje nustatydama galimybę Seimui pašalinti asmenị iš pareigų, panaikinti Seimo nario mandatą, siekia, kad eidami savo pareigas Konstitucijos 74 straipsnyje nurodyti asmenys paklustų Tautos priimtai Konstitucijai, besąlygiškai vadovautųsi Konstitucija ir teise, Tautos ir Lietuvos valstybės interesais. Konstitucinis Teismas 2004 m. gegužès 25 d. nutarime yra konstatavęs, kad apkaltos institutas yra Respublikos Prezidento ir kitų Konstitucijos 74 straipsnyje nurodytų valstybės pareigūnų veiklos viešos demokratinès kontrolès ir jų atsakomybès visuomenei būdas, apimantis inter alia galimybę pašalinti juos iš užimamų pareigų, jeigu jie nevykdo savo ìsipareigojimo vadovautis tik Konstitucija ir teise, asmeninius ar grupinius interesus iškelia virš visuomenès interesų, savo veiksmais diskredituoja valstybès valdžią ${ }^{3}$. Tai viena iš valstybinès bendruomenès - pilietinès Tautos savisaugos priemonių, gynimosi nuo minètų aukščiausių

2 Apkaltos (angl. impeachment) institutas susiformavo XIV a. Anglijoje. (Išsamiau žr. Esmein, A. Konstitucinès teisès principai (prancūzu ir palyginamieji). T. 1, d. 1. Kaunas: Teisininkų draugijos leidinys, 1932, p. 178.)

3 Lietuvos Respublikos Konstitucinio Teismo 2004 m. gegužès 25 d. nutarimas. Valstybès žinios. 2004, Nr. 85-3094. 
valstybės valdžios pareigūnų, nepaisančių Konstitucijos ir teisės, savo veiksmais diskredituojančių valstybės valdžią, būdas, kai jų igaliojimai nutraukiami Seimo - Tautos atstovybès - sprendimu. Konstitucijoje, remiantis Tautos suvereniteto ir valdžių padalijimo teorijomis, įtvirtinta „trijų valdžių pareigūnų“ apkaltos koncepcija, pagal kurią apkalta gali būti taikoma Respublikos Prezidentui, Seimo nariams ir aukščiausių grandžių teisèjams ${ }^{4}$.

Konstitucijos 74 straipsnyje nustatyti trys savarankiški apkaltos pagrindai: 1) šiurkštus Konstitucijos pažeidimas; 2) priesaikos sulaužymas; 3) paaiškejjus, jog padarytas nusikaltimas. Apkaltos procesas gali būti pradètas esant bent vienam iš šių pagrindų; Konstitucijos 74 straipsnis nereikalauja, kad būtų visi trys apkaltos pagrindai ar koks nors jų derinys. Konstitucijos 74 straipsnyje nustatytas pagrindų, kuriems esant valstybès pareigūnai gali būti pašalinti iš pareigų, gali būti panaikintas Seimo nario mandatas, sąrašas yra išsamus (baigtinis), jis negali būti plečiamas ar siaurinamas įstatymais.

Konstitucijos pažeidimas, kaip ir priesaikos sulaužymas ar nusikaltimo padarymas, yra teisès pažeidimas. Konstitucijoje nèra ir negali būti pateiktas konkrečių konstitucinių deliktų sąrašas. Konstitucijoje ịtvirtintas bendro pobūdžio reikalavimas: Respublikos Prezidentas, Konstitucinio Teismo pirmininkas ir teisejjas, Aukščiausiojo Teismo pirmininkas ir teisejjas, Apeliacinio teismo pirmininkas ir teisejjas, Seimo narys privalo savo pareigas vykdyti taip, kad nepažeistų (šiurkščiai) Konstitucijos, nesulaužytų priesaikos; nurodyti asmenys taip pat negali padaryti nusikaltimo. Galima teigti, jog Konstitucija nustato tam tikrą 74 straipsnyje nurodytų asmenų veiklos modelį, tam tikras veiklos taisykles ir standartus, kurių neleidžiama pažeisti. Nurodyti asmenys turi ypatingą konstitucinị statusą, Konstitucijoje jiems nustatytos atitinkamos garantijos (imunitetai ir kt.) - tai suponuoja ir jų ypatingą atsakomybę valstybinei bendruo-

Vaičaitis, V. Prezidento apkalta 2003-2004. Vilnius: Teisinès informacijos centras, 2005, p. 15. 
menei - pilietinei Tautai ${ }^{5}$. Jeigu nurodyti asmenys šiurkščiai pažeidžia Konstituciją, sulaužo priesaiką, taip pat paaiškèja, jog padarytas nusikaltimas - už tai jie apkaltos proceso tvarka gali būti pašalinami iš pareigų, gali būti panaikinamas Seimo nario mandatas.

Teisès mokslinèje literatūroje nurodoma, kad lietuviško apkaltos modelio specifiką lemia tai, kad jame susipina politiniai ir teisiniai elementai ${ }^{6}$. Konstitucijoje nustatyta, kad apkaltos procese dalyvauja dvi valstybès valdžios institucijos: Seimas (politinė institucija) ir Konstitucinis Teismas (teisinė institucija). Kiekviena iš jų turi tik jai nustatytus igaliojimus: Seimas inicijuoja apkaltą; Konstitucinis Teismas teikia išvadą, ar pareigūno, kuriam pradèta apkalta, veiksmai neprieštarauja Konstitucijai; gavęs Konstitucinio Teismo išvadą, kad pareigūno, kuriam pradèta apkalta, veiksmai prieštarauja Konstitucijai, Seimas sprendžia, ar asmenị pašalinti iš pareigų, ar panaikinti Seimo nario mandatą.

Respublikos Prezidentas, Konstitucinio Teismo pirmininkas ir teisejjai, Aukščiausiojo Teismo pirmininkas ir teisejjai, Apeliacinio teismo pirmininkas ir teisejjai, Seimo nariai konstitucinès atsakomybės subjektais tampa tik po to, kai, prieš pradèdami eiti savo pareigas, prisiekia. Tol, kol šie asmenys nèra davę priesaikos, jie negali būti traukiami konstitucinèn atsakomybèn, t. y. jiems apkalta negalima.

\section{Nusikaltimas - savarankiškas apkaltos pagrindas}

Minėta, kad Konstitucijos 74 straipsnyje nustatyti trys savarankiški apkaltos pagrindai: 1) šiurkštus Konstitucijos pažeidimas; 2) priesaikos sulaužymas; 3) paaiškejjus, jog padarytas nusikaltimas. Šiame straipsnyje nèra tiesiogiai ịtvirtinta, kada turi būti atlikti veiksmai, už kuriuos nurodytiems asmenims galima apkalta: ar tik už veiksmus, kuriuos jie

5 Lietuvos Respublikos Konstitucinio Teismo 2004 m. gegužès 25 d. nutarimas. Valstybès žinios. 2004, Nr. 85-3094.

6 Jarašiūnas, E. Lietuvos Respublikos Konstitucinis Teismas ir aukštujų valstybès pareigūnų apkalta: kelios aktualios problemos. Jurisprudencija. 2006, Nr. 2, p. 41. 
padarè eidami Konstitucijos 74 straipsnyje nurodytas pareigas, ar ir už veiksmus, kuriuos jie padare $i k i$ užimdami nurodytas pareigas.

Konstitucinis Teismas taip pat nèra išaiškinęs, ar apkalta galima ir už veiksmus, kuriuos asmenys padarė iki užimdami Konstitucijos 74 straipsnyje nurodytas pareigas. Seime vykstančios diskusijos rodo, kad Seimo narių nuomonè šiuo klausimu iš esmès skiriasi: vieni teigia, kad apkalta galima tik už veiksmus, kuriuos nurodyti asmenys padarè $e i$ dami Konstitucijos 74 straipsnyje išvardytas pareigas ${ }^{7}$, o kiti aiškina, kad apkalta galima ir už veiksmus, kuriuos asmenys padarè $i k i$ jas $u \check{z}$ imdami ${ }^{8}$.

Seimo statuto 227 straipsnyje nustatyta, kad „Apkaltos procesas yra parlamentinè procedūra, kurią Seimas taiko Konstitucijos 74 straipsnyje nurodytiems asmenims dèl Konstitucijai prieštaraujančių jų veiksmų, padarytų einant pareigas, siekdamas išspręsti tokių asmenų konstitucinès atsakomybės klausimą"9. Taigi, pagal Seimo statutą Konstitucijos 74 straipsnyje nurodytiems asmenims apkaltos procesas gali būti taikomas tik už Konstitucijai prieštaraujančius veiksmus, kuriuos asmenys padarè eidami Konstitucijos 74 straipsnyje nurodytas pareigas, o už veiksmus, kuriuos jie padarè iki jas užimdami, apkalta negalima.

Yra pagrindo abejoti, ar Seimo statuto 227 straipsnyje nustatytas teisinis reguliavimas neprieštarauja Konstitucijai. Sprendžiant, ar Konstitucijos 74 straipsnyje nurodytiems asmenims apkalta gali būti taikoma tik tuo atveju, jeigu jie šiurkščiai pažeidè Konstituciją, sulaužè priesaiką, padarè nusikaltimą eidami Konstitucijos 74 straipsnyje išvardytas pareigas, ar ji gali būti taikoma ir už veiksmus, kuriuos padarè iki jas užimdami, esminès reikšmès, mūsų nuomone, turi tai, koks yra apkaltos pagrindas.

7 Graužinienè, L. LRT televizija. Laida ,Savaite“ “ (2016 m. vasario 7 d.).

8 Kubilius, A. Straipsnyje „Seimas pradèjo apkaltos procesa V. Gapšiui“. Delfi. $2016 \mathrm{~m}$. balandžio $7 \mathrm{~d}$.

9 Lietuvos Respublikos Seimo statutas. Valstybès žinios. 1999, Nr. 5-97. 
Konstitucijos 74 straipsnio formuluote, kad „Respublikos Prezidentą, Konstitucinio Teismo pirmininką ir teisejjus, Aukščiausiojo Teismo pirmininką ir teisejjus, Apeliacinio teismo pirmininką ir teisèjus, Seimo narius, šiurkščiai pažeidusius Konstitucija arba sulaužiusius priesaiką, Seimas gali pašalinti iš užimamų pareigų, panaikinti Seimo nario mandatą", reiškia, kad veiksmus, kuriais šiurkščiai pažeidžiama Konstitucija arba sulaužoma priesaika, nurodyti asmenys turi būti padarę eidami Konstitucijos 74 straipsnyje išvardytas pareigas. Tokia išvada kyla iš Konstitucijoje nustatyto teisinio reguliavimo, pagal kurị Respublikos Prezidentas, Konstitucinio Teismo pirmininkas ir teisejjai, Aukščiausiojo Teismo pirmininkas ir teisejjai, Apeliacinio teismo pirmininkas ir teisejjai, Seimo nariai prieš pradèdami eiti savo pareigas privalo prisiekti. Duodami priesaiką visi nurodyti asmenys prisiekia inter alia gerbti ir vykdyti Konstituciją. Jie negali pradèti eiti savo pareigų tol, kol neprisiekia. Konstitucinis Teismas $2004 \mathrm{~m}$. gegužès $25 \mathrm{~d}$. nutarime yra konstatavęs, kad priesaikos sulaužymas yra šiurkštus Konstitucijos pažeidimas, o šiurkštus Konstitucijos pažeidimas yra priesaikos sulaužymas ${ }^{10}$. Akivaizdu, kad priesaiką sulaužyti (kartu - šiurkščiai pažeisti Konstituciją) gali tik šią priesaiką davęs asmuo. Nedavęs priesaikos asmuo negali jos sulaužyti. Vadinasi, veiksmai, kuriuos Konstitucijos 74 straipsnyje nurodyti asmenys atliko iki pradedami eiti šiame straipsnyje išvardytas pareigas, negali būti vertinami kaip veiksmai, kuriais asmuo šiurkščiai pažeide Konstitucija, sulaužè priesaiką, nes asmuo nebuvo įsipareigojęs nepažeisti Konstitucijos, nesulaužyti priesaikos. Už tokius veiksmus, mūsų nuomone, apkalta negalima.

Kitaip vertintina situacija, kai apkaltos pagrindas yra „paaiškejjus, jog padarytas nusikaltimas“. Minėta, kad nusikaltimo padarymas yra savarankiškas apkaltos pagrindas. Nekyla abejonių, kad Konstitucijos 74 straipsnis nustato, jog šiame straipsnyje nurodytiems asmenims apkalta turi būti pradèta, jeigu jie nusikaltima padaré eidami Konstitucijos 74

${ }^{10}$ Lietuvos Respublikos Konstitucinio Teismo 2004 m. gegužès 25 d. nutarimas. Valstybès žinios. 2004, Nr. 85-3094. 
straipsnyje išvardytas pareigas. Neturi reikšmès, koks nusikaltimas padarytas, - apkaltos procesas turi būti pradètas visais atvejais, kai paaiškèja, kad asmenys, eidami Konstitucijos 74 straipsnyje išvardytas pareigas, padarè nusikaltimą ${ }^{11}$. Tokiu atveju Seimas turi ịvertinti, ar tuo nusikaltimu nèra diskredituojama valstybės valdžia, ar nėra pakertamas visuomenès pasitikejjimas valstybès institucijomis ir jų pareigūnais. Seimas turi spręsti, ar toks asmuo gali ir toliau eiti pareigas, ar turi būti panaikintas jo Seimo nario mandatas. Konstitucinis Teismas 1999 m. gegužès 11 d. nutarime yra konstatavęs, kad „duodamas sutikimą patraukti asmenị baudžiamojon atsakomybèn, Seimas kartu apsisprendžia, kad bylos faktines aplinkybes tirs ne Seimo sudaryta specialioji tyrimo komisija, bet teisinès institucijos - tardymas ir teismas. Tai reiškia, kad jeigu teismas pripažins asmenį kaltu padarius nusikaltimą, vèliau nereikès pateikti atskiro siūlymo pradèti apkaltą dẻl nusikaltimo padarymo ${ }^{\text {"12 }}$.

11 Teisès mokslinèje literatūroje kartais teigiama, kad, ,apkaltos proceso tvarka iš pareigų turi būti pašalintas toks asmuo, kuris nusikaltimu kartu šiurkščiai pažeidžia Konstituciją, sulaužo priesaiką“. (Žr. Statkevičius, M. Apkaltos padariniai. Teisé. 2005, Nr. 56, p. 58-59.) Šs teiginys yra dviprasmiškas, nes jis gali būti aiškinamas ir taip, esą pagal Konstitucijos 74 straipsnị apkalta galima tik už tokị nusikaltimą, kuriuo šiurkščiai pažeidžiama Konstitucija, sulaužoma priesaika. Pabrėžtina, kad Konstitucijos 74 straipsnio nuostata, kad apkalta galima ,paaiškejjus, jog padarytas nusikaltimas“, reiškia, kad nusikaltimas yra savarankiškas apkaltos pagrindas, Konstitucija nenumato, kad apkalta galima tik už tokị nusikaltimą, kuriuo kartu šiurkščiai pažeidžiama Konstitucija, sulaužoma priesaika. Bet kokio nusikaltimo padarymas yra pagrindas apkaltai, bet padaryto nusikaltimo pobūdis gali turèti ittakos Seimui sprendžiant, ar už jị asmenị pašalinti iš pareigų, panaikinti jo Seimo nario mandatą. Pagal Konstituciją tik Seimas sprendžia, ar asmenị pašalinti iš pareigų, ar panaikinti jo Seimo nario mandatą, taigi, ir už tokị nusikaltimą, kuriuo šiurkščiai pažeista Konstitucija, sulaužyta priesaika. Sutinkame su teiginiu, kad „,asmuo, kuris nusikaltimu kartu šiurkščiai pažeidė Konstituciją, sulaužè priesaiką, turi būti pašalintas iš pareigų“, nes Konstitucija netoleruoja tokios situacijos, kai Konstitucijos 74 straipsnyje nurodytas pareigas toliau eina asmuo, kuris šiurkščiai pažeidè Konstituciją, sulaužè priesaiką. Bet Seimas gali nutarti ir kitaip: nors asmuo padarè nusikaltimą, kuriuo šiurkščiai pažeidè Konstituciją, sulaužė priesaiką, Seimas gali nutarti nepašalinti asmens iš pareigų, nepanaikinti jo Seimo nario mandato.

12 Lietuvos Respublikos Konstitucinio Teismo 1999 m. gegužès 11 d. nutarimas. Valstybès žinios. 1999, Nr. 42-1345; atitaisymas: 1999, Nr. 43. 
Iš Konstitucinio Teismo $2004 \mathrm{~m}$. gegužès $25 \mathrm{~d}$. nutarime suformuluotos oficialios konstitucinès doktrinos, pagal kurią už šiurkštų Konstitucijos pažeidima, priesaikos sulaužymą apkaltos proceso tvarka iš pareigų pašalintas asmuo niekada ateityje negali užimti tokių Konstitucijoje išvardytų pareigų, kurias asmuo gali pradeti eiti tik po to, kai duoda Konstitucijoje nustatytą priesaiką, kyla ir tai, kad, kaip minètame nutarime yra konstatavęs Konstitucinis Teismas, „Seimui, sprendžiančiam, ar apkaltos proceso tvarka pašalinti asmenị iš užimamų pareigų, panaikinti jo Seimo nario mandatą už nusikaltimo padarymą, pagal Konstituciją tenka atsakomybè išsiaiškinti, ar nusikaltimo padarymu kartu nebuvo šiurkščiai pažeista Konstitucija, sulaužyta priesaika“. Formuluotė „Seimui pagal Konstituciją tenka atsakomybe išsiaiškinti, ar nusikaltimo padarymu kartu nebuvo šiurkščiai pažeista Konstitucija, sulaužyta priesaika" reiškia, kad Seimas, spręsdamas, ar apkaltos proceso tvarka pašalinti asmenį iš užimamų pareigų, panaikinti jo Seimo nario mandatą už nusikaltimo padarymą, turi kreiptis ị Konstitucinị Teismą prašydamas pateikti išvadą, ar nusikaltimo padarymu kartu nebuvo šiurkščiai pažeista Konstitucija, sulaužyta priesaika. Jeigu Konstitucinis Teismas padarytų išvadą, kad nusikaltimu kartu buvo šiurkščiai pažeista Konstitucija, sulaužyta priesaika, asmuo, kuris apkaltos proceso tvarka būtų pašalintas iš pareigų, būtų panaikintas jo Seimo nario mandatas, niekada ateityje negalètų užimti tokių Konstitucijoje nurodytų pareigų, kurias asmuo gali pradèti eiti tik po to, kai duoda Konstitucijoje nustatytą priesaiką.

Nors Konstitucinio Teismo $2004 \mathrm{~m}$. gegužès 25 d. nutarime expressis verbis nerašoma, kada turi būti padarytas nusikaltimas, - ar iki asmeniui pradedant eiti Konstitucijos 74 straipsnyje nurodytas pareigas, ar jas einant, - galima teigti, kad minėtame Konstitucinio Teismo nutarime rašoma apie nusikaltimą, kurị asmuo padarè eidamas nurodytas pareigas, nes jeigu asmuo padarè nusikaltimą iki pradedamas jas eiti, tokiu nusikaltimu jis, mūsų nuomone, negali sulaužyti priesaikos, šiurkščiai pažeisti Konstitucijos, nes jis nebuvo davęs priesaikos, nebuvo ịsipareigojęs gerbti ir vykdyti Konstituciją, jos nepažeisti. 
Konstitucijos 74 straipsnyje nèra eksplicitiškai įtvirtintos išlygos, kad jame nurodytiems asmenims apkaltos procesas negali būti pradètas už nusikaltimą, kuri jie padarè iki pradėdami eiti pareigas. Konstitucijos 74 straipsnis, mūsų nuomone, nedraudžia jame nustatytą teisinị reguliavimą aiškinti plačiau, inter alia taip, kad pagal Konstitucijos 74 straipsnị Konstitucinio Teismo pirmininkui ir teisèjui, Aukščiausiojo Teismo pirmininkui ir teisejui, Apeliacinio teismo pirmininkui ir teisèjui, Seimo nariui apkaltos procesas turi būti pradètas ne tik už nusikaltima, kurị jie padare eidami šiame straipsnyje išvardytas pareigas, bet ir už tokị nusikaltimą, kurị padarè iki pradėdami jas eiti, o apkaltinamasis teismo nuosprendis jų atžvilgiu ìsiteisëja jiems einant Konstitucijos 74 straipsnyje nurodytas pareigas.

Pagal Konstitucijos 74 straipsnị, mūsų nuomone, ir Respublikos Prezidentas turètų būti traukiamas konstitucinèn atsakomybèn, jeigu jam einant Respublikos Prezidento pareigas paaiškètų, kad jis padarè nusikaltimą iki pradedamas eiti Respublikos Prezidento pareigas.

Sprendžiant, ar pagal Konstitucijos 74 straipsnị jame nurodytiems asmenims apkaltos procesas turi būti pradètas ir už tokị nusikaltima, kurị jie padarè $i k i$ pradėdami eiti pareigas, esminès reikšmės turi kelios aplinkybès.

Pirma. Konstitucijos 74 straipsnio nuostata, kad „Respublikos Prezidentą, Konstitucinio Teismo pirmininką ir teisejjus, Aukščiausiojo Teismo pirmininką ir teisèjus, Apeliacinio teismo pirmininką ir teisèjus, Seimo narius Seimas gali pašalinti iš užimamų pareigų, panaikinti Seimo nario mandatą paaiškejjus, jog padarytas nusikaltimas“, aiškintina Konstitucijos preambuleje nustatytų Tautos siekių, t. y. atviros, teisingos, darnios pilietinès visuomenès ir teisinès valstybès siekių, bei konstitucinio teisinès valstybès principo kontekste (Konstitucinio Teismo 2004 m. kovo 31 d. išvada). Aiškinimas, kad pagal Konstitucijos 74 straipsnị esa negalima pradèti apkaltos proceso už nusikaltimą, kurị asmuo padarė $i k i$ pradėdamas eiti šiame straipsnyje išvardytas pareigas, būtų konstituciškai nepagristas, nes jis būtų nesuderinamas su 
Konstitucijos preambuleje ittvirtintais imperatyvais, konstituciniu teisinès valstybės principu. Toks aiškinimas reikštų inter alia tai, kad net tuo atveju, kai Konstitucijos 74 straipsnyje nurodytas asmuo, užimantis šiame straipsnyje išvardytas pareigas (išskyrus Respublikos Prezidentą), būtų nuteistas už nusikaltimą, kurị jis padarė $i k i$ pradėdamas eiti pareigas, pavyzdžiui, septynerių metų laisvės atėmimo bausme, o apkaltinamasis nuosprendis jo atžvilgiu būtų priimtas ir ịsiteisėtų jam užimant Konstitucijos 74 straipsnyje nurodytas pareigas, ir asmuo būtų uždarytas ị laisvès atėmimo įstaigą, jam apkalta esq̨ vis tiek būtų negalima?! Akivaizdu, kad Konstitucijos 74 straipsnio taip aiškinti negalima, nes Konstitucija nenumato ir nesuponuoja, kad šiame straipsnyje nurodytų teismų teisejju ar Seimo nariu - Tautos atstovu - būtų asmuo, laisvès atėmimo ịstaigose atliekantis teismo nuosprendžiu jam paskirtą laisvès atėmimo bausmę, o Seimas esq̨ negali spręsti, ar toki asmeni pašalinti iš atitinkamų teisèjo pareigų, panaikinti tokio asmens Seimo nario mandatą. Pagal Konstitucijos 74 straipsnị, konstitucinius atsakingo valdymo ir teisinès valstybės principus toks asmuo ne tik gali būti, bet ir turi būti pašalintas iš atitinkamų teisèjo pareigų, turi būti panaikintas asmens Seimo nario mandatas.

Antra. Konstitucija yra vientisas aktas (6 str. 1 d.). Iš Konstitucijos vientisumo kyla ir tai, kad aiškinant kiekvienos atskiros Konstitucijos nuostatos turinį būtina matyti jos sąsajas su kitomis Konstitucijos nuostatomis, o atskiroje Konstitucijos nuostatoje ịtvirtintą teisinį reguliavimą vertinti visuminio konstitucinio reguliavimo kontekste. Konstitucijos 74 straipsnio nuostata, kad apkaltos procesas turi būti pradètas „paaiškejjus, jog padarytas nusikaltimas“, yra susijusi su kitomis Konstitucijos nuostatomis, inter alia su Konstitucijos 108 straipsnio 5 punkto nuostatomis. Konstitucijos 108 straipsnyje nustatyti Konstitucinio Teismo teisẻjo ịgaliojimų nutrūkimo pagrindai. Pagal ši straipsnị Konstitucinio Teismo teisejjo igaliojimai nutrūksta, kai: 1) pasibaigia igaliojimų laikas; 2) jis miršta; 3) atsistatydina; 4) negali eiti savo pareigų dèl sveikatos būklès; 5) Seimas ji pašalina iš pareigu apkaltos pro- 
ceso tvarka. Matome, kad Konstitucijos 108 straipsnyje nèra nustatyta, jog Konstitucinio Teismo teisèjo igaliojimai nutrūksta, kai jo atžvilgiu isiteiseja apkaltinamasis teismo nuosprendis. Tačiau tai jokiu būdu nereiškia, kad Konstitucijos 108 straipsnis esq neleidžia už nusikaltimo padarymą nuteisto Konstitucinio Teismo teisejjo pašalinti iš pareigų. Priešingai, jeigu paaiškètų, kad Konstitucinio Teismo teisėjas padarè nusikaltimą ir apkaltinamasis teismo nuosprendis įsiteisètų, Seimas pagal Konstitucijos 74 straipsnị ne tik galètų, bet ir privalètų tokio asmens atžvilgiu pradèti apkaltos procesą ir pašalinti ji iš Konstitucinio Teismo teisèjo pareigų. Pabrěžtina, kad tokiu atveju neturi reikšmés, kada buvo padarytas nusikaltimas: ar asmeniui einant Konstitucinio Teismo teisejjo pareigas, ar $i k i$ jas pradedant eiti, nes Konstitucija nenumato ir netoleruoja tokios situacijos, kad Konstitucinio Teismo teisejo pareigas galètų toliau eiti ir konstitucinị teisingumą vykdyti asmuo, kurị teismas nuteisè už nusikaltimo padarymą, taip pat ir tokio nusikaltimo, kurị asmuo padarè $i k i$ pradėdamas eiti Konstitucinio Teismo teisejjo pareigas, o teismo apkaltinamasis nuosprendis jo atžvilgiu buvo priimtas ir isiteisejjo jam einant Konstitucinio Teismo teisèjo pareigas.

Analogiškai Konstitucijos 74 straipsnyje nustatytas apkaltos pagrindas „paaiškèjus, jog padarytas nusikaltimas“ turètų būti aiškinamas sprendžiant, ar šiuo pagrindu galima pradèti apkaltos procesą Aukščiausiojo Teismo pirmininkui ir teisejjui, Apeliacinio teismo pirmininkui ir teisèjui.

Tai, kada asmuo padaré nusikaltimą, - ar iki pradèdamas eiti Konstitucinio Teismo pirmininko ar teisejjo, Aukščiausiojo Teismo pirmininko ar teisèjo, Apeliacinio teismo pirmininko ar teisèjo pareigas, ar eidamas atitinkamo teismo pirmininko ar teisejjo pareigas, - turi reikšmés tik tuo aspektu, kad jeigu asmuo nusikaltimą padarytų eidamas nurodytas pareigas, Seimas privalètų kreiptis ị Konstitucini Teismą prašydamas pateikti išvadą, ar nusikaltimu kartu nèra šiurkščiai pažeista Konstitucija, sulaužyta priesaika. Jeigu asmuo nusikaltimą padarytų iki pradedamas eiti nurodytas pareigas, Seimas, mūsų nuomone, netu- 
rètu prašyti Konstitucinio Teismo išvados, ar nusikaltimu kartu nèra šiurkščiai pažeista Konstitucija, sulaužyta priesaika, nes tokiu nusikaltimu asmuo negali sulaužyti priesaikos, šiurkščiai pažeisti Konstitucijos, - jis nebuvo davęs atitinkamos priesaikos, nebuvo įsipareigojęs gerbti ir vykdyti Konstituciją, jos nepažeisti.

Trečia. Sprendžiant, ar pagal Konstitucijos 74 straipsnị apkaltos proceso tvarka Seimo nario mandatą galima panaikinti paaiškèjus, kad jis nusikaltimą padarè $i k i$ tapdamas Seimo nariu, o apkaltinamasis nuosprendis jo atžvilgiu ịsiteisẻjo jam einant Seimo nario pareigas, būtina matyti šio straipsnio sąsajas su Konstitucijos 63 straipsniu, kuriame nustatyti Seimo nario igaliojimų nutrūkimo pagrindai. Pagal ši straipsnị Seimo nario ịgaliojimai nutrūksta, kai: 1) pasibaigia ịgaliojimų laikas arba susirenka ị pirmąji posèdị pirmalaikiuose rinkimuose išrinktasis Seimas; 2) jis miršta; 3) atsistatydina; 4) teismas pripažįsta ji neveiksniu; 5) Seimas panaikina jo mandata apkaltos proceso tvarka; 6) rinkimai pripažįstami negaliojančiais arba šiurkščiai pažeidžiamas rinkimų ịstatymas; 7) pereina dirbti arba neatsisako darbo, nesuderinamo su Seimo nario pareigomis; 8) netenka Lietuvos Respublikos pilietybès. Konstitucijos 63 straipsnyje nèra nustatyta, kad Seimo nario ịgaliojimai nutrūksta, kai ịsiteisèja jo atžvilgiu priimtas teismo apkaltinamasis nuosprendis. Tokio Seimo nario igaliojimų nutrūkimo pagrindo nèra, nes rengiant Konstituciją buvo vadovaujamasi nuostata, jog vien teismo priimto apkaltinamojo nuosprendžio Seimo nario atžvilgiu nepakanka, kad jis netektų Seimo nario mandato, - sprendimą, ar už nusikaltimo padarymą panaikinti Seimo nario mandatą, turi priimti tik Seimas. Todèl Konstitucijos 63 straipsnyje nustatyta, kad Seimo nario igaliojimai nutrūksta, kai „Seimas panaikina jo mandatą apkaltos proceso tvarka" (5 punktas), o vienas iš apkaltos pagrindų, kaip minèta, yra „paaiškejjus, jog padarytas nusikaltimas“ (Konstitucijos 74 straipsnis).

Konstitucijos 63 straipsnio 5 punkte nustatytas Seimo nario igaliojimu nutrūkimo pagrindas, „kai Seimas panaikina Seimo nario manda- 
tą apkaltos proceso tvarka" ir Konstitucijos 74 straipsnyje numatytas Seimo nario apkaltos pagrindas „paaiškejus, jog padarytas nusikaltimas“ reiškia, kad Seimo nario mandatas gali būti panaikintas ir už nusikaltimą, kurị Seimo narys padarè eidamas Seimo nario pareigas, ir už nusikaltimą, kurị asmuo padarè $i k i$ pradèdamas jas eiti, o teismo apkaltinamasis nuosprendis jo atžvilgiu buvo priimtas ir įsiteisejjo jam einant Seimo nario pareigas. Pagal Konstitucinio Teismo suformuluotą oficialią konstitucinę doktriną skirtusi tik apkaltos pasekmés. Jeigu apkalta būtų pradèta už nusikaltimą, kurị asmuo padarè eidamas Seimo nario pareigas, Seimas turi kreiptis ị Konstitucinị Teismą ir prašyti išvados, ar tokiu nusikaltimu nèra šiurkščiai pažeista Konstitucija, sulaužyta priesaika. Jeigu Konstitucinis Teismas padarytų išvadą, kad nusikaltimu šiurkščiai pažeista Konstitucija, sulaužyta priesaika, o Seimas apkaltos proceso tvarka panaikintų Seimo nario mandatą, toks asmuo niekada ateityje negalètų užimti pareigų, kurių ejjimo pradžia susijusi su Konstitucijoje įvardytos priesaikos davimu. Jeigu apkalta būtų pradèta už nusikaltimą, kurị asmuo padare iki pradėdamas eiti Seimo nario pareigas, o teismo apkaltinamasis nuosprendis jo atžvilgiu būtų priimtas ir įsiteisètų jam einant Seimo nario pareigas, Seimas, mūsų nuomone, neturètų kreiptis ị Konstitucinị Teismą ir prašyti išvados, ar tokiu nusikaltimu nèra šiurkščiai pažeista Konstitucija, sulaužyta priesaika, nes asmuo padaré nusikaltimą iki duodamas priesaiką, vadinasi, jis negalejo jos sulaužyti, kartu negalëjo šiurkščiai pažeisti Konstitucijos. Jeigu Seimas apkaltos proceso tvarka panaikintų tokio asmens Seimo nario mandatą, ši aplinkybė neuždraustų tokiam asmeniui ateityje būti renkamam Seimo nariu, jeigu jis bus atlikęs teismo nuosprendžiu paskirtą bausmę ir atitiks kitas Konstitucijoje nustatytas sąlygas.

Ketvirta. Konstitucijos 31 straipsnio 1 dalyje nustatyta, kad „asmuo laikomas nekaltu, kol jo kaltumas neįrodytas įstatymo nustatyta tvarka ir pripažintas įsiteisèjusiu teismo nuosprendžiu“. Vadinasi, tik teismas gali konstatuoti, jog asmuo padarė nusikaltimą, tik teismas gali pripažinti asmenį kaltu padarius nusikaltimą. Konstitucijos 74 straipsnyje for- 
muluotès „teismo nuosprendis“ nèra, šiame straipsnyje vartojama kita formuluotè, - „paaiškejjus, jog padarytas nusikaltimas“. Konstitucijos 31 straipsnio 1 dalies ir 74 straipsnio formuluotès skiriasi ne tik žodine išraiška, bet ir turiniu. Šių formuluočių skirtumas nèra atsitiktinis, jị lemia tai, kad pagal Konstitucijos 86 straipsnio 1 dalį Respublikos Prezidentas, kol eina savo pareigas, negali būti patrauktas baudžiamojon atsakomybėn. Vadinasi, pagal Konstituciją Seimas neturi igaliojimų spręsti, ar leisti Respublikos Prezidentą patraukti baudžiamojon atsakomybèn, o teismas neturi igaliojimu konstatuoti, kad Respublikos Prezidentas padare nusikaltima. Tačiau Konstitucijos 74 straipsnyje ir 86 straipsnio 2 dalyje nustatyta, kad Respublikos Prezidentas gali būti pašalintas iš pareigų, jeigu „paaiškèja, jog padarytas nusikaltimas“. Šią nuostatą aiškinant Konstitucijos 86 straipsnio 1 dalies nuostatos, kad „Respublikos Prezidentas, kol eina savo pareigas, negali būti patrauktas baudžiamojon atsakomybèn“, kontekste, darytina išvada, jog faktą, kad Respublikos Prezidentas padarè nusikaltimą, gali konstatuoti ne teismas, o tik Seimas.

Taigi, Konstitucijos 74 straipsnio nuostata, kad „Respublikos Prezidentas, Konstitucinio Teismo pirmininkas ir teisèjai, Aukščiausiojo Teismo pirmininkas ir teisejjai, Apeliacinio teismo pirmininkas ir teisejjai gali būti pašalinti iš pareigų, gali būti panaikintas Seimo nario mandatas, kai paaiškèja, jog padarytas nusikaltimas" reiškia, jog faktą, kad Konstitucinio Teismo pirmininkas ar teisėjas, Aukščiausiojo Teismo pirmininkas ar teisejjas, Apeliacinio teismo pirmininkas ar teisëjas, Seimo narys padarè nusikaltimą gali konstatuoti du subjektai, t. y. ir teismas, ir Seimas, o faktą, kad nusikaltimą padare Respublikos Prezidentas, gali konstatuoti tik vienas subjektas, t. y. Seimas. Tai, kad Seimas gali konstatuoti, kad nusikaltimą padarè bet kuris Konstitucijos 74 straipsnyje nurodytas asmuo (kiekvienas iš jų, taip pat ir Respublikos Prezidentas), țtvirtinta oficialioje konstitucinèje doktrinoje ${ }^{13}$. Kartu reikètų atkreipti dèmesị i tai, kad Konstitucinis Teismas $2004 \mathrm{~m}$. balandžio 15 d. nutarime yra konstatavęs,

${ }^{13}$ Lietuvos Respublikos Konstitucinio Teismo 2004 m. kovo 31 d. išvada. Valstybès žinios. 2004, Nr. 49-1600. 
kad Seimas be teisinių institucijų tyrimo gali konstatuoti nusikaltimo padarymo faktą tik tuo atveju, kai nusikaltimas yra akivaizdus, o „tais atvejais, kai nusikaltimo padarymo faktas nèra akivaizdus, Seimas pagal Konstituciją negali vykdyti apkaltos nusikaltimo padarymo pagrindu tol, kol nèra priimtas ir įsiteisèjęs teismo apkaltinamasis nuosprendis" ${ }^{\text {"14 }}$. Konstitucinio Teismo nutarimuose konstatuota ir tai, kad „Seimo statute gali būti nustatyta tokia apkaltos tvarka, kad būtų atsižvelgta ị konstitucinių pagrindų skirtumus"15.

Penkta. Konstitucijos 74 straipsnyje nurodyti asmenys, taigi, ir Seimo nariai, - tai ypač svarbias pareigas einantys valstybès pareigūnai, jų statusas ypatingas. Iš Konstitucijos preambuleje ịtvirtintų Tautos siekių, t. y. atviros, teisingos, darnios pilietinès visuomenès ir teisinès valstybès siekių, taip pat iš konstitucinio teisinès valstybès principo šiems asmenims kyla inter alia ypač aukšti moraliniai reikalavimai, jų reputacija turi būti nepriekaištinga. Jeigu asmuo $i k i$ pradėdamas eiti Seimo nario pareigas padarè nusikaltimą, už kurị apkaltinamasis nuosprendis jo atžvilgiu buvo priimtas ir įsiteisèjo jam būnant Seimo nariu, Seimas pagal Konstituciją privalo pradèti apkaltos procesą ir turi spręsti, ar panaikinti Seimo nario mandata apkaltos proceso tvarka. Seimas negali nusišalinti nuo šio klausimo sprendimo. Konstitucinis Teismas 1999 m. gegužès 11 d. nutarime yra konstatavęs, kad „jeigu teismas pripažins asmenị kaltu padarius nusikaltimą, vèliau nereikès teikti atskiro siūlymo pradèti apkaltą dèl nusikaltimo padarymo" ${ }^{\text {"16. }}$.

Apibendrinant galima teigti, kad Seimo statuto 227 straipsnis tiek, kiek neleidžiama apkaltos proceso tvarka pašalinti iš pareigų Konstitu-

${ }^{14}$ Lietuvos Respublikos Konstitucinio Teismo 2004 m. balandžio 15 d. nutarimas. Valstybès žinios. 2004, Nr. 56-1948.

15 Lietuvos Respublikos Konstitucinio Teismo 1999 m. gegužès 11 d. nutarimas. Valstybès žinios. 1999, Nr. 42-1345; atitaisymas: 1999, Nr. 43; Lietuvos Respublikos Konstitucinio Teismo $2000 \mathrm{~m}$. kovo $30 \mathrm{~d}$. nutarimas. Valstybès žinios. 2000, Nr. 28-784.

${ }^{16}$ Konstitucinio Teismo 1999 m. gegužès 11 d. nutarimas. Valstybés žinios. 1999, Nr. 42-1345. 
cijos 74 straipsnyje išvardytų asmenų, panaikinti Seimo nario mandato, paaiškejjus, kad nurodyti asmenys nusikaltima padare iki užimdami atitinkamai Respublikos Prezidento, Konstitucinio Teismo pirmininko, šio teismo teisejjo, Aukščiausiojo Teismo pirmininko, šio teismo teisèjo, Apeliacinio teismo pirmininko, šio teismo teisèjo, Seimo nario pareigas, prieštarauja Konstitucijos 74 straipsniui, konstituciniam teisinès valstybès principui.

Pagal Konstituciją tik Konstitucinis Teismas turi igaliojimus oficialiai aiškinti Konstituciją. Kol Konstitucinis Teismas nèra pateikęs oficialios konstitucinès doktrinos, ar pagal Konstitucijos 74 straipsnị apkalta galima ir už veiksmus, kuriuos asmenys padarè iki užimdami šiame straipsnyje nurodytas pareigas, tol Konstitucijos 74 straipsnis gali būti aiškinamas skirtingai. Seimo narių grupe 2016 m. vasario $19 \mathrm{~d}$. kreipèsi i Konstitucinį Teismą, prašydama spręsti, ar Seimo statuto 227 straipsnis, pagal kurị apkalta galima tik už veiksmus, padarytus einant Konstitucijos 74 straipsnyje išvardytas pareigas, neprieštarauja Konstitucijos 74 straipsniui. Jeigu su panašiu prašymu ị Konstitucinị Teismą kreiptųsi

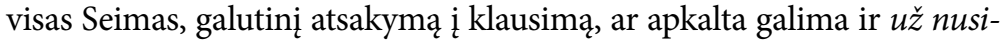
kaltima, kurị asmuo padaré iki užimdamas nurodytas pareigas, gautume greičiau. Seimas pasirinko kitą kelią: nelaukdamas Konstitucinio Teismo sprendimo, ar Seimo statuto 227 straipsnis neprieštarauja Konstitucijai, $2016 \mathrm{~m}$. balandžio $7 \mathrm{~d}$. nutarimu nutare pradèti apkaltos procesą Seimo nariui V. Gapšiui ir kreipèsi ị Konstitucinị Teismą išvados, ar Seimo nario V. Gapšio veiksmai prieštarauja Konstitucijai ir ar jis „gali eiti Seimo nario pareigas po to, kai jam įsiteisejjo teismo apkaltinamasis nuosprendis“. Nagrinèdamas Seimo narių grupès kreipimąsi ir Seimo prašymą pateikti išvadą, Konstitucinis Teismas turètų išaiškinti Konstitucijos 74 straipsnio turinị ir tuo aspektu, ar pagal Konstituciją apkalta galima tik už veiksmus, kuriuos Konstitucijos 74 straipsnyje nurodyti asmenys padarè eidami šiame straipsnyje numatytas pareigas, ar apkalta galima ir už veiksmus, padarytus iki jas užimant. Kartu turètų būti suformuluota oficiali konstitucinė doktrina, ar, traukiant Konstitucijos 74 straipsny- 
je nurodytus asmenis konstitucinèn atsakomybėn $u \check{z}$ veiksmus, kuriuos jie padare iki užimdami nurodytas pareigas, yra būtina Konstitucinio Teismo išvada. Mūsų nuomone, jos nereikia. Kad ir kokią konstitucinę doktriną suformuluos Konstitucinis Teismas, vienas dalykas yra aiškus: Konstitucinis Teismas atsisakys nagrinèti Seimo prašymą pateikti išvadą, ar V. Gapšys "gali eiti Seimo nario pareigas po to, kai jam įsiteisejo teismo apkaltinamasis nuosprendis“, nes Konstitucinis Teismas pagal Konstituciją neturi igaliojimų spręsti, ar Seimo narys gali toliau eiti pareigas, kai jo atžvilgiu issiteisejo apkaltinamasis teismo nuosprendis. Tai gali spręsti tik pats Seimas (Konstitucijos 74 str.).

\section{Išvados}

Apkaltos institutas yra Konstitucijos 74 straipsnyje nurodytų valstybès pareigūnų veiklos viešos demokratinès kontrolès ir jų atsakomybès visuomenei būdas, kai jų igaliojimai nutraukiami Seimo sprendimu, nes jie šiurkščia pažeidžia Konstituciją, sulaužo priesaiką, padaro nusikaltimą. Konstitucijos 74 straipsnyje nèra tiesiogiai ịtvirtinta, kada turi būti atlikti veiksmai, už kuriuos šiame straipsnyje nurodytiems asmenims galima apkalta: ar tik už veiksmus, kuriuos jie padarė eida$m i$ Konstitucijos 74 straipsnyje nurodytas pareigas, ar ir už veiksmus, kuriuos padarè iki jas užimdami. Konstitucinis Teismas taip pat nèra išaiškinęs, ar apkalta galima ir už veiksmus, kuriuos asmenys padarè iki užimdami minètame straipsnyje nurodytas pareigas. Sistemiškai aiškinant Konstituciją galima teigti, kad pagal Konstitucijos 74 straipsnị Konstitucinio Teismo pirmininkui ir teisejjui, Aukščiausiojo Teismo pirmininkui ir teisejjui, Apeliacinio teismo pirmininkui ir teisejjui, Seimo nariui apkaltos procesas turi būti pradètas ne tik už nusikaltima, kurị jie padarè eidami Konstitucijos 74 straipsnyje išvardytas pareigas, bet ir už tokị nusikaltimą, kurị padarè iki pradėdami jas eiti, o apkaltinamasis teismo nuosprendis jų atžvilgiu ịsiteiseja jiems einant Konstitucijos 74 straipsnyje nurodytas pareigas. 


\section{Literatūra}

Esmein, A. Konstitucinès teisès principai (prancūzu ir palyginamieji). T. 1, d. 1. Kaunas, 1932.

Graužinienè, L. Komentaras LRT televizijos laidoje „Savaite“. $2016 \mathrm{~m}$. vasario $7 \mathrm{~d}$.

Jarašiūnas, E. Lietuvos Respublikos Konstitucinis Teismas ir aukštųjų valstybės pareigūnų apkalta: kelios aktualios problemos. Jurisprudencija, 2006, Nr. 2.

Kubilius, A. (Komentaras straipsnyje „Seimas pradejo apkaltos procesą V. Gapšiui). Delfi. $2016 \mathrm{~m}$. balandžio $7 \mathrm{~d}$.

Statkevičius, M. Apkaltos padariniai. Teisè. 2005, Nr. 56.

Vaičaitis, V. Prezidento apkalta 2003-2004. Vilnius: Teisinès informacijos centras, 2005.

Lietuvos Respublikos Seimo statutas. Valstybès žinios. 1999, Nr. 5-97.

Lietuvos Respublikos Seimo 2016 m. balandžio 7 d. nutarimas Nr. XII- 2289 „Dèl apkaltos Lietuvos Respublikos Seimo nariui Vytautui Gapšiui pradžios ir kreipimosi ị Lietuvos Respublikos Konstitucinị Teismą“. Teisès aktų registras (TAR) 2016-04-07, identifikavimo kodas 2016-08285.

Lietuvos Respublikos Konstitucinio Teismo 1999 m. gegužès 11 d. nutarimas. Valstybés žinios. 1999, Nr. 42-1345; atitaisymas: 1999, Nr. 43.

Lietuvos Respublikos Konstitucinio Teismo 2000 m. kovo $30 \mathrm{~d}$. nutarimas. Valstybès žinios. 2000, Nr. 28-784.

Lietuvos Respublikos Konstitucinio Teismo 2004 m. kovo $31 \mathrm{~d}$. išvada. Valstybès žinios. 2004, Nr. 49-1600.

Lietuvos Respublikos Konstitucinio Teismo $2004 \mathrm{~m}$. balandžio 15 d. nutarimas. Valstybès žinios. 2004, Nr. 56-1948.

Lietuvos Respublikos Konstitucinio Teismo 2004 m. gegužès 25 d. nutarimas. Valstybès žinios. 2004, Nr. 85-3094. 


\section{IS IT POSSIBLE TO INSTITUTE IMPEACHMENT AGAINST A MEMBER OF THE SEIMAS FOR A CRIME COMMITTED BEFORE BECOMING A MEMBER OF THE SEIMAS}

\section{VyTAUTAS SINKEVIČIUS}

\section{Summary}

Keywords: concept of impeachment; grounds for impeachment; legal effects of impeachment.

The institute of impeachment is a method of public democratic control over the activity of the state officials listed in Article 74 of the Constitution and a method of holding such officials liable when their powers are terminated by means of a resolution of the Seimas due to the fact that such officials have grossly violated the Constitution, breached the oath, or committed a crime. Article 74 of the Constitution does not directly indicate when the actions serving as grounds for impeaching the persons specified in this article are performed: whether impeachment is possible only for actions performed at the time when they were holding the positions specified in Article 74 of the Constitution, or whether also for actions performed by them before obtaining the positions pointed out in the same article. The Constitutional Court has not yet provided its interpretation whether impeachment is also possible for actions performed by the respective persons before they obtained the positions specified in in Article 74 of the Constitution. A systemic interpretation of the Constitution allows asserting that, according to Article 74 of the Constitution, impeachment must be instituted against the President and justices of the Constitutional Court, the President and justices of the Supreme Court, the President and judges of the Court of Appeal, as well as any members of the Seimas, not only for a crime committed by them at the time when they were holding the positions provided for in Article 74 of the Constitution, but also for a crime committed by them before obtaining the positions specified in the same article where a convicting court judgment in respect of them comes into force at the time when they are holding the positions specified in Article 74 of the Constitution. 